\title{
Change of fungi and mycotoxin in hulled barley under different conditions and period
}

\author{
Hyeonheui Ham*, Jiseon Baek, Mijeong Lee, Theresa Lee, Sung-Kee Hong, \\ Seungdon Lee \\ Microbial Safety Team, National Instituite of Agricultural Sciences, Wangu 55365, Korea
}

\section{저장 중 겉보리에 발생하는 곰팡이와 곰팡이독소 변화}

\author{
함현희* · 백지선 · 이미정 · 이데레사 · 홍성기 · 이승돈 \\ 국립농업과학원
}

\begin{abstract}
To establish good storage practices for hulled barley against mycotoxin contamination, we measured occurrence of fungi and mycotoxin in hulled barley grains under various storage conditions. Hulled barley grains collected from two places were stored in five different warehouses: 1) two without temperature control, 2) one with temperature controlled at $12^{\circ} \mathrm{C}, 3$ ) a chamber set at $15{ }^{\circ} \mathrm{C} / 65 \%$ relative humidity, and 4) one seed storage set at $10^{\circ} \mathrm{C}$. The samples were stored for six month with temperature and relative humidity monitored regularly. Every stored samples were retrieved after $0,1,3$, and 6 month to investigate fungal and mycotoxin contamination. From the stored grains, Fusarium, Epicoccum, Alternaria, and Drechslera spp. were frequently detected. In the warehouses without temperature control, Fusarium and Alternaria spp. constantly decreased, whereas Drechslera spp. increased along with storage period. In the other warehouses with temperature controlled, Fusarium spp. decreased slowly and more than $2.5 \mathrm{log} \mathrm{CFU} / \mathrm{g}$ of Fusarium spp. were detected after 6 month storage. The level of nivalenol was maintained during 0-3 month but increased after 6 month storage. There was no difference in the nivalenol levels between the warehouses. Therefore reducing storage period less than 6 months could be more effective to control nivalenol contamination in hulled barley grains.
\end{abstract}

Key words : hulled barley, fungi, mycotoxin, storage

\section{서 론}

곰팡이독소는 곰팡이가 분비하는 2 차대사산물로 매우 적은 양으로도 인축에 심각한 해를 끼칠 수 있는데 농산물 에서 주로 문제가 되는 곰팡이독소는 Fusarium, Aspergillus 및 Penicillium 속 곰팡이가 분비한다(1). 이 중 Fusarium 속 곰팡이는 작물의 재배 단계에 주로 감염되는 식물병원균 으로, 국내에는 Fusarium graminearum과 F. asiaticum 등의

*Corresponding author. E-mail : hhham@korea.kr Phone : 82-63-238-3399, Fax : 82-63-238-3840

Received 31 August 2017; Revised 11 October 2017; Accepted 17 October 2017.

Copyright (c) The Korean Society of Food Preservation. All rights reserved.
붉은곰팡이가 주로 발생하며 벼, 보리 등 곡류에 데옥시니 발레놀(deoxynivalenol, DON)과 니발레놀(nivalenol, NIV) 을 오염시킨다(2). 작물의 재배 중 감염된 붉은곰팡이는 수확 후 곡물에 남아 있다가 적정한 수분조건이 주어지면 증식하여 곰팡이독소를 생성할 수 있다(3). Aspergillus 및 Penicillium 속 곰팡이는 곡물의 저장 중에 주로 발생하며 아플라톡신 또는 오크라톡신 A 등을 생성할 수 있다 $(1,3,4)$.

독성곰팡이 외에도 다양한 곰팡이가 저장 중 곡물에 오 염될 수 있다. Taligoola 등(5)에 의하면 쌀을 $25^{\circ} \mathrm{C}$ 에서 270 일 동안 저장했을 때 Aspergillus 속이 가장 많이 발견되었고 Penicillium, Eurotium 및 Fusarium 속 순으로 관찰되어 건조 한 조건에서 잘 자라는 저장 곰팡이가 쌀에 우점하였음을 알 수 있었다. 포장에서 오염되는 곰팡이는 Fusarium 속 외에도 Alternaria, Epicoccum, Nigrospora 속 등이 있다. 
Pinciroli 등(6)은 벼를 실험실에 1년간 저장했을 때 Alternaria, Nigrospora, Epicoccum, Bipolaris, Curvularia, Cladosporium, Fusarium, Penicillium 및 Aspergillus 속 순으로 빈번하게 관찰되었다고 보고하였다. 이는 곡물의 상태나 저장 조건 에 따라 우점하는 곰팡이의 종류가 달라질 수 있음을 시사 한다.

곡류를 저장하는 방법은 일반적으로 포대에 담아 저장하 는 상온 및 저온저장과 산물 저장 방식인 사일로 저장이 있다(7). 수확한 보리는 곰팡이가 증식하지 않도록 곧바로 건조하여 수분함량을 $14 \%$ 이하로 유지하고, 장기 저장할 경우 유해한 미생물이나 해충의 번식을 예방하기 위해 저온 에 저장하는 것이 좋다. GAP 생산가이드에 따르면 맥류를 $15^{\circ} \mathrm{C}$, 상대습도 $65 \%$ 이하로 저장할 것을 권장하고 있다(8). 또한 벼는 산물저장방식을 주로 사용하여 통풍과 순환이 원활하며, 도정단계를 거치면서 대부분의 곰팡이와 독소가 제거되지만(9), 보리는 포대에 담아 상온에 저장하는 경우 가 많으며, 이 중 겉보리는 보리차나 엿기름 등으로 이용할 때 도정을 하지 않아 곰팡이나 곰팡이독소의 오염 가능성이 비교적 높다. Fusarium 등 포장 곰팡이는 곡물의 껍질부분 에 주로 오염되므로 $(6,10,11)$ 겉보리의 경우 곰팡이독소를 특히 주의해야 한다.

기존 연구에서 겉보리를 상온창고와 저온창고에 저장하 여 붉은곰팡이와 니발레놀의 변화 및 저장 온도와 수분함 량의 영향을 조사한 바 있다(12). 그러나 조사 대상이 붉은 곰팡이에 국한되어있고 저장장소가 한정되어 다양한 저장 조건에서 발생할 수 있는 곰팡이와 곰팡이독소를 파악하기 어려웠다. 따라서 본 연구에서는 다양한 저장환경 중 발생 가능한 곰팡이독소에 대한 예방 전략을 수립하고자 상온창 고 2곳, 저온창고, 종자저장고 및 맥류저장용 온·습도 유지 장치에서 겉보리의 저장 기간에 따라 발생하는 주요 곰팡이 와 곰팡이독소를 조사하고 곰팡이독소 안전 저장조건을 탐색하였다.

\section{재료 및 방법}

시료 채취 및 저장

겉보리는 서로 다른 두 지역(시료 1, 시료 2)에서 2016년 도에 수확한 것을 사용하였다. 겉보리는 $10 \mathrm{~kg}$ 씩 마대자루 에 담아 맥류를 저장하는 상온창고 2 곳, 저온창고 $\left(12^{\circ} \mathrm{C}\right.$ 이 하), 종자저장고 $\left(10^{\circ} \mathrm{C}\right)$ 및 항온항습실 $\left(15^{\circ} \mathrm{C}, 65 \%\right)$ 에 2016 년 7월 7일부터 2017년 7월 6일까지 6개월 간 저장하였다. 각각의 저장고에는 온·습도 측정계 $(174 \mathrm{H}$, Testo Co., Sparta, NJ, USA)를 설치하여 한 시간 간격으로 저장소 내부 의 온도와 상대습도를 측정하였으며 $0,1,3,6$ 개월 후 시료 를 $1 \mathrm{~kg}$ 씩 채취하여 곰팡이와 곰팡이독소를 조사하였다.

\section{곰팡이 발생빈도 조사 및 균 동정}

겉보리의 곰팡이 발생빈도를 조사하기 위해 겉보리 낟알 을 $1 \%$ 차아염소산나트륨에 1 분간 표면살균하고, 멸균수로 2회 세척하였다. 이 중 무작위로 105 립을 streptomycin (Biosesang Inc., Seongnam, Korea) $600 \mu \mathrm{g} / \mathrm{mL}$ 이 첨가된 potato dextrose agar(PDA, BD Co., Sparks, MD, USA)에 치상하여 $25^{\circ} \mathrm{C}$ 배양기에서 5 일간 배양한 후 발생한 곰팡이 를 관찰하였다. 곰팡이의 분리 및 동정을 위해 곰팡이 균사 를 $\mathrm{PDA}$ 에 옮긴 후 $25^{\circ} \mathrm{C}$ 배양기에서 5일간 배양하여 $\mathrm{DNA}$ 를 추출하였으며, DNA 추출법은 Lee 등(13)의 방법과 동일하 였다. 분리한 DNA는 internal transcribed spacer(ITS4, ITS5) 유전자를 증폭하여 미국 국립생물정보센터(https://blast.ncbi. nlm.nih.gov/Blast.cgi)에서 염기서열을 비교 동정하였으며, Fusarium 속의 경우 translation elongation factor 1-a 영역을 증폭하여 Fusarium ID(http://isolate.fusariumdb.org)에서 최 종 동정하였다(14-15).

\section{붉은곰팡이병균 오염정도 조사}

겉보리 $2 \mathrm{~g}$ 을 ball mill(MM400, Retsch Co., Haan, Germany)을 이용하여 15회/초의 진동으로 20 초간 분쇄한 것을 $4^{\circ} \mathrm{C}$ 에서 1 분간 식힌 후, 다시 20 초간 분쇄하였다. 이 중 $1 \mathrm{~g}$ 을 $1 \%$ peptone water $9 \mathrm{~mL}$ 에 희석한 후 $250 \mu \mathrm{L}$ 를 pentachloronitrobenzene(Sigma-aldrich Co., St. Louis, MO, $\mathrm{USA})$ 이 첨가된 rose bengal-glycerine-urea(RbGU) 배지에 도말하였다. 배지는 van Wyk 등(16)의 방법과 동일하게 제조하였으며, 사용한 시약은 glycerol(Biosesang Inc., Seongnam, Korea), urea(ProGEN Co., Seongnam, Korea), L-Alanine(Sigma-aldrich Co.), rose bengal(Sigma-aldrich Co.), agar(BD Co., Sparks, MD, USA)이었다. 도말한 선택배 지는 $25^{\circ} \mathrm{C}$ 에서 5 일 간 배양한 후 균총의 수를 계수하였다.

\section{곰팡이독소 분석}

겉보리 $5 \mathrm{~g}$ 에 3 차 증류수 $20 \mathrm{~mL}$ 을 가하고 30 분간 진탕하 여 독소를 추출하였다. 추출물은 $3,600 \mathrm{rpm}$ 에서 10 분간 원 심분리한 후 상등액을 여과지(Whatman No. 1, GE Healthcare, Buckinghamshire, UK)로 여과하였다. 여과액은 $5 \mathrm{~mL}$ 을 DON, NIV 정제컬럼(DON-NIVTM WB, Vicam Co., Milford, MA, USA)에 초당 1방울씩 통과시킨 후 phosphate salined buffer(Oxoid, Hampshire, UK) $10 \mathrm{~mL}$ 과 3차 증류수 $10 \mathrm{~mL}$ 을 차례로 통과시켜 컬럼을 세척하였다. 컬럼에 메탄 올(Fisher Scientific Korea Ltd., Seoul, Korea) $0.5 \mathrm{~mL}$ 과 acetonitrile (Fisher Scientific Korea Ltd.) $1.5 \mathrm{~mL}$ 를 차례로 가하여 독소를 용출한 후 질소가스로 건고시키고 이동상 $1 \mathrm{~mL}$ 에 녹여 $0.22 \mu \mathrm{m}$ 시린지필터(PTFE $13 \mathrm{~mm}, \mathrm{RDTECH}$ Inc., Korea)로 여과한 후, UPLC-PDA(Waters Acquity UPLC ${ }^{\circledR}$ H Class, Waters Corp., Milford, MA, USA)로 분석하였다. 분석에 사용한 컬럼은 $\mathrm{UPLC}^{\circledR} \mathrm{BEH} \mathrm{C}_{18}, 1.7 \mu \mathrm{m}, 2.1 \times 100$ 
$\mathrm{mm}$ (Waters Corp.)이며, 이동상은 물:아세토니트릴:메탄올 $=90: 5: 5$, 유속은 $0.3 \mathrm{~mL} / \mathrm{min}$, 시료주입량은 $10 \mu \mathrm{L}$, 분석시간 은 10 분, $\mathrm{UV}$ 검출기의 파장은 $218 \mathrm{~nm}$ 으로 하였다.

\section{통계처리}

겉보리의 저장장소 또는 저장기간 간 곰팡이독소 오염량 에 차이가 있는지 알아보기 위해 각각 일원분산분석(SAS 9.4, SAS Institute Inc., cary, NC, USA)을 수행하였다. 유의 수준 $\mathrm{p}<0.05$ 에서 귀무가설을 검정한 후 기각한 경우 Duncan의 다중검정을 통해 차이를 구분하고 수치 옆에 위 첨자 $a$ 와 $b$ 로 표시하였다.

\section{결과 및 고찰}

저장환경과 보리 수분함량의 변화

상온창고 2 곳과 저온창고, 항온항습실 및 종자저장고의 온.습도 측정결과는 Fig. 1.과 같다. 7월과 8월 상온창고 1 의 평균온도는 $28-32^{\circ} \mathrm{C}$ 인 반면 창고 2 는 $18-28^{\circ} \mathrm{C}$ 로 조금 낮았다. 9월부터 이듬해 1월까지는 상온창고 2곳 모두 온도 가 점차 낮아지며 유사한 온도변화를 보였다. 습도는 상온 창고 1이 57-68\%, 창고 2가 59-69\%로 서로 유사하였다. 저온창고는 온도를 $12^{\circ} \mathrm{C}$ 로 설정하였으나 7-10월 동안 실제 측정 온도는 $12-15^{\circ} \mathrm{C}$ 로 나타났으며 11 월부터는 낮은 외부 기온을 반영하여 11 월 $8^{\circ} \mathrm{C}, 12$ 월 $5^{\circ} \mathrm{C}$ 및 1 월 $3{ }^{\circ} \mathrm{C}$ 로 낮추어
가동하였다. 저온창고의 습도는 $65-77 \%$ 로 상온창고의 습 도보다 높았다. 항온항습실은 7 월 $\left(18^{\circ} \mathrm{C}\right)$ 을 제외하고 $14^{\circ} \mathrm{C}$ 를 유지하였으며 습도는 62-66\%이었다. 종자저장고는 온도 $7-11^{\circ} \mathrm{C}$, 습도 $35-66 \%$ 로 온도는 가장 낮았으나 습도 변화는 가장 컸다.

보리의 수분함량은 창고의 환경과 저장기간에 따라 변화 하였다(Fig. 2). 수집한 겉보리는 수확 후 수분함량을 $14 \%$ 이하로 건조시킨 것으로, 저장 1 개월 후에는 종자저장고에 보관한 것을 제외하고 모두 수분함량이 증가하였다. 시료 의 수분함량은 종자저장고에 보관한 것이 가장 낮았으며 항온항습실이 그 뒤를 이었다. 상온창고와 저온창고에 보 관했던 시료는 초기 수분함량이 유사하였으나 저장 6개월 후에는 상온창고에 보관했던 시료의 수분함량이 더 낮았 다. 또한 상온창고와 저온창고에서는 저장기간 동안 동일 창고 내의 시료 간 수분함량 차이가 최대 $3.6 \%$ 까지 벌어져 같은 장소에 저장하더라도 시료 간 수분함량에 차이가 발생 할 수 있음을 나타냈다.

\section{저장기간에 따른 곰팡이 오염}

저장 중 보리에 오염된 주요 곰팡이 속은 Fusarium, Epicoccum, Alternaria 및 Drechslera 이었으며 이중 붉은곰 팡이 $(F$. graminearum과 F. asiaticum)의 오염빈도가 저장 초기 약 $74.9 \%$ 로 가장 높았다(Fig. 3). 붉은곰팡이는 저장기 간이 경과할수록 오염 빈도가 감소하였다. 특히 상온창고 는 저장 6 개월 후 붉은곰팡이 오염빈도가 $2 \%$ 로 감소율이
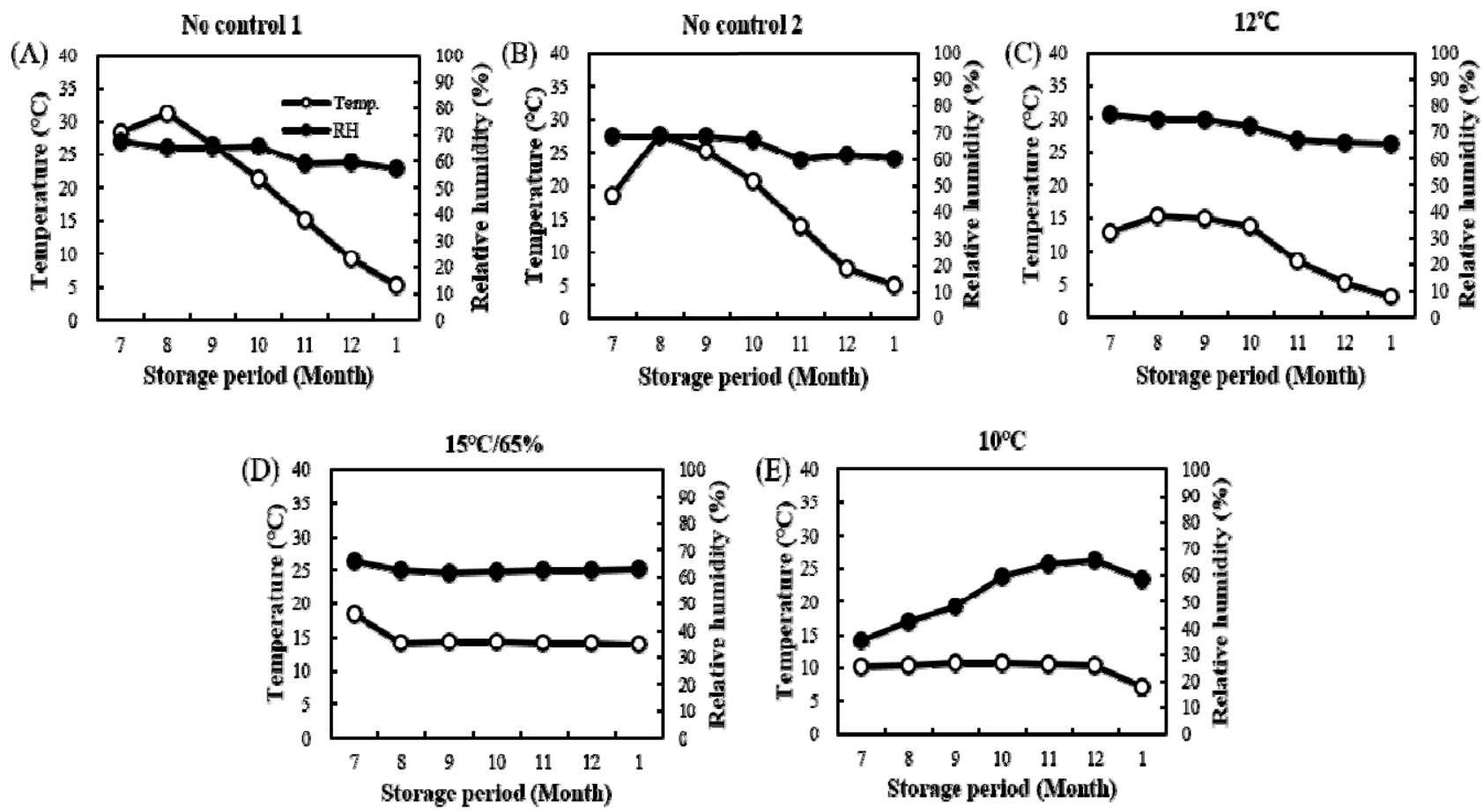

Fig. 1. Change of temperature and relative humidity during various storage conditions.

A-B, Storage without temperature or humidity control; C, Storage at $12{ }^{\circ} \mathrm{C}$ or below; D, Storage at $15{ }^{\circ} \mathrm{C}$ and $65 \%$ humidity; E, Storage at $10{ }^{\circ} \mathrm{C}$. 


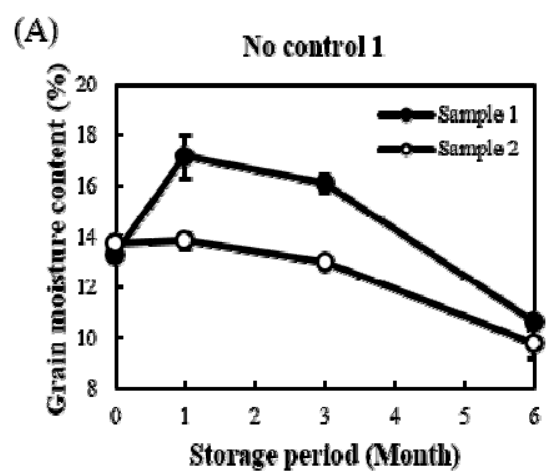

(D)

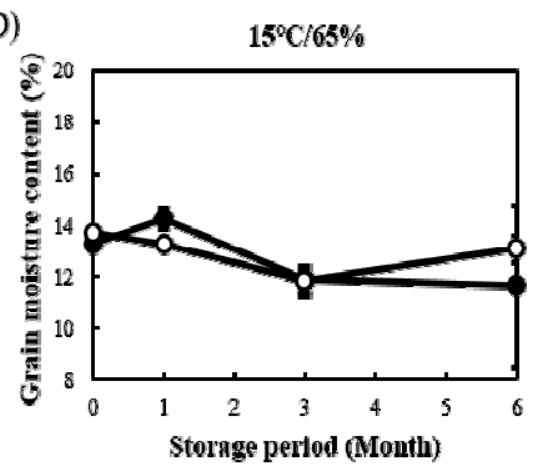

(B)

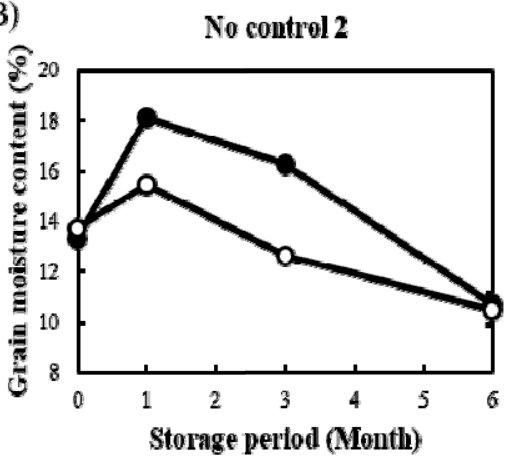

(E)

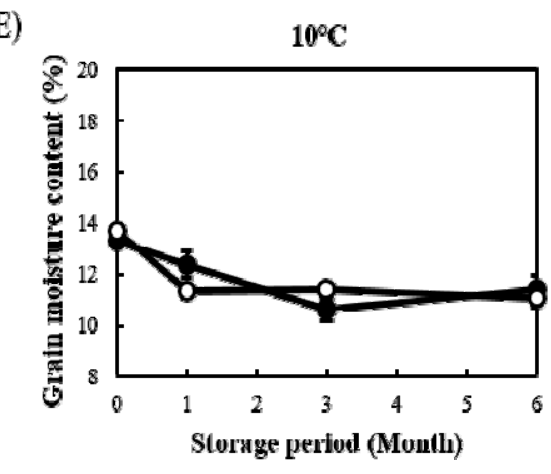

(C)

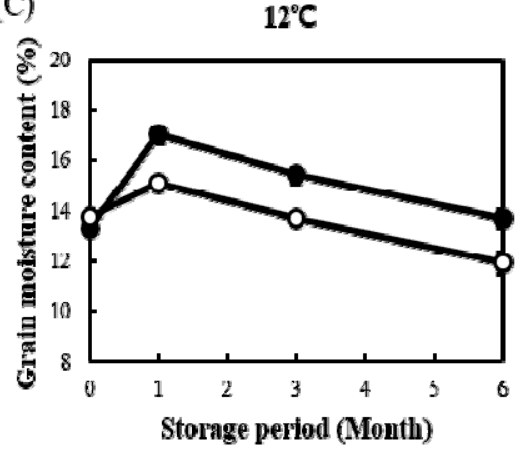


가장 높았으며 그 외의 저장소에서는 $35 \%$ 내외로 나타났 다. 또한 후자리움 선택배지인 RbGU에서 붉은곰팡이 개체 를 조사한 결과 상온창고는 초기 약 $3 \log \mathrm{CFU} / \mathrm{g}$ 에서 저장 6개월 후 $0.4 \log \mathrm{CFU} / \mathrm{g}$ 이하로 감소한 반면 저온창고, 항온 항습실 및 종자저장고에서는 $2.5 \log \mathrm{CFU} / \mathrm{g}$ 이상을 유지하 였다(Fig. 4). 곡물에 오염된 붉은곰팡이가 저장기간에 따라 감소하는 현상은 다른 연구에서도 보고되었다. Beattie(17) 는 Fusarium 속이 $85 \%$ 오염된 보리를 상온 등 다양한 조건 에서 저장하였더니 저장 7 개월 후 66-76\%로 감소하였다고 보고하였다. 특히 $24 \pm 5^{\circ} \mathrm{C}$ 의 공기가 통하는 환경에서 저장 한 경우 Fusarium 속이 $66.3 \%$ 로 감소하여 $5^{\circ} \mathrm{C}$ 에 냉장 보관 한 경우(73.7\%)보다 감소폭이 높았다. 또한 여러 연구에서 곡물의 저장기간이 경과할수록 Fusarium 속의 오염 비율이 감소하였다고 보고하였다(18-20). Fusarium의 생육조건은 온도 $5-30^{\circ} \mathrm{C}\left(\right.$ 적온 $\left.15-25^{\circ} \mathrm{C}\right)$, 종자수분함량 $17 \%$ 이상이라고 알려져 있다(20-21). 그러나 본 연구에서 온.습도가 가장 낮으며, 저장시료의 수분함량이 $14 \%$ 이하였던 종자저장고 에서 Fusarium 속이 $3 \log \mathrm{CFU} / \mathrm{g}$ 이상을 유지한 것은 주목할 만하다. 일반적으로 저장기간이 경과할수록 포장 곰팡이는 감소하고 저장 곰팡이는 증가하는 양상을 보이며(17-20) 온도와 수분함량 등 저장 환경이 이들 곰팡이의 생육에 영향을 미치는 동시에 곡물낟알에서 일부 곰팡이의 점유를 일으킬 수 있다(22,23). Homdork(23)는 밀을 $15^{\circ} \mathrm{C}$, 상대습도 $56 \%$ 의 저온건조 조건에서 36 주 동안 저장했을 때 저장 후기에 Fusarium 등 일부 포장 곰팡이 오염립이 증가하였고 밀 종자의 발아율과 활력이 높았음을 보고하였다. 반면 2 $5^{\circ} \mathrm{C}, 90 \%$ 의 고온다습 조건에 보관한 밀에서는 저장기간이 경과할수록 Fusarium 오염립이 감소하여 36주 후 전혀 검 출되지 않았으며, 종자 발아율과 활력도 낮았다. 이는 본 연구에서 저온건조 조건인 종자저장고에 보관한 시료에서 붉은곰팡이가 가장 오랫동안 생존한 것과 유사한 결과이

(A)

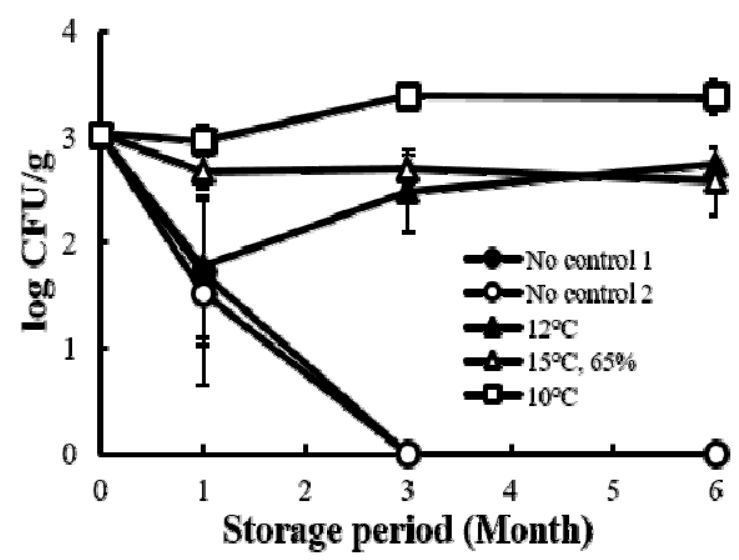

다. 또한 항온항습실에서도 붉은곰팡이가 오랜 기간 생존 한 것을 볼 때, 이러한 결과는 저온에서 저장 전 오염되었던 포장 곰팡이가 그대로 남아있는 반면 저장 곰팡이의 증식은 억제되는 것으로 볼 수 있다. 한편 상온창고에 저장한 보리 는 포장 곰팡이 오염은 감소되지만 저장 곰팡이 증식의 위험이 있다(17-20).

Epicoccum과 Alternaria도 포장 곰팡이로 상온창고에서 저장기간에 따라 오염율이 감소하는 경향을 보였다. Epicoccum 속은 저장 전 오염율이 약 $26.3 \%$ 였으며, 저장기 간이 경과할수록 상온창고와 저온창고에서는 오염율이 감 소하였으나, 항온항습실과 종자저장고에서는 감소하지 않 았다. Alternaria 속은 초기 오염율이 약 $25.7 \%$ 로 세 번째로 높았으며, 저장 후기로 갈수록 상온창고에서 오염율이 감 소하였으나 저온창고, 항온항습실 및 종자저장고에서는 감 소하지 않았다. Pinciroli(6)에 의하면 벼를 품종별로 실험실 에 보관하면서 4, 8 및 12 개월 후 곰팡이를 조사했을 때 Epicoccum 은 초기 17.2-38.0\%의 빈도로 검출되었던 것이 8개월 후 2.4-48.4\%, 12 개월 후 0-1.9\%로 검출빈도가 감소 하여 본 연구의 상온창고 저장 결과와 유사하였다. 그러나 Alternaria의 경우 초기 오염율이 55.7-62\%로 본 연구결과 보다 2배정도 높았으며, 8개월 후 55.4-77.1\%, 12개월 후 $50.5-55.6 \%$ 로 검출되어 저장기간 경과에도 오염율이 크게 감소하지 않았다. 반면 White 등(24)에 의하면 쌀보리를 온도와 습도를 달리하여 저장하였을 때 Alternaria alternata 는 초기 $11-38 \%$ 의 오염율을 보였으나 저장 1 년 후 거의 검출되지 않아 온·습도에 관계없이 감소하는 경향을 보였 다. 한편 저장 곰팡이인 Penicillium은 초기 0-5.2\%에서 12 개월 후 3.7-9.7\%로 증가하였고, Aspergillus는 초기에 검출 되지 않다가 12 개월 후 5.6-23.5\%로 검출되어 Epicoccum 보다 높았으나 Alternaria 보다는 낮은 검출빈도를 보였다. Aspergillus와 Penicillium은 저장 후기에 검출 빈도가 증가

(B)

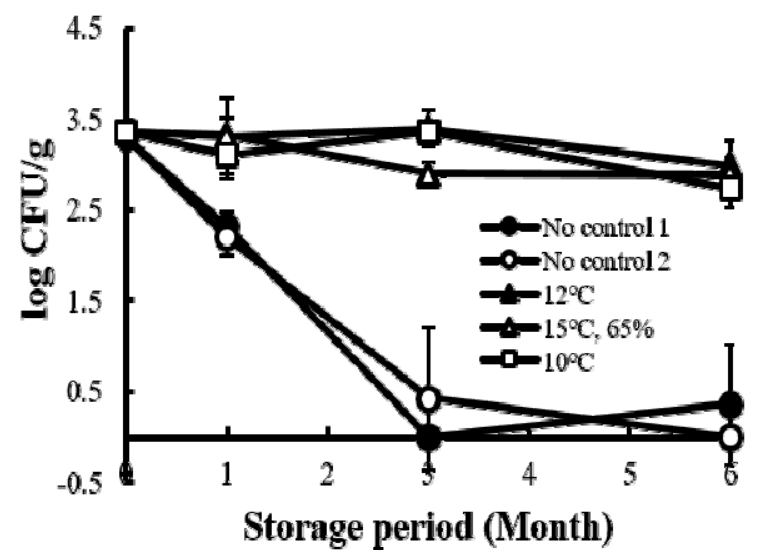

Fig. 4. Change of Fusarium spp. frequency in hulled barley during storage. A, Sample 1; B, Sample 2. 
하여 저장 후기 저장 곰팡이의 우점현상을 확인할 수 있었 다. 즉 곡물의 저장 기간, 곰팡이의 초기 오염율 및 곰팡이 간 상호작용이 저장 곰팡이 증식과 포장 곰팡이 감소에 영향을 미친 것으로 보인다. 본 연구에서 Aspergillus와 Penicillium속은 $1 \%$ 이하로 검출되었다. 그러나 보리를 상 온에 저장할 경우 Aspergillus나 Penicillium 등 저장 곰팡이 로 인한 곰팡이독소의 오염 가능성이 높아지고, 저온에 저 장할 경우 Fusarium 이나 Alternaria 등 포장 곰팡이에 의한 곰팡이독소 발생 가능성이 높아진다.

Drechslera 속은 저장 초기에 검출되지 않다가 저장 후기 에 검출 빈도가 증가하였다. D. graminea는 종자 전염성의 식물병원균으로 보리에 줄무늬병을 일으키며 생육적온은 $25^{\circ} \mathrm{C}$, 생육온도범위는 $15-35^{\circ} \mathrm{C}$ 로 알려져 있다(25). Wiewióra 와 Pronczuk(26)에 의하면 라이그라스 종자를 상온에 보관 하였을 때 Drechslera 속이 3년간 생존하였으며, 오히려 수확 직후보다 검출빈도가 증가하였다고 보고하였다. 또한 본 연구에서는 Drechslera 속의 검출빈도가 붉은곰팡이의 검출빈도와 반비례하는 양상을 보였는데, 이는 저장 초기 $\mathrm{PDA}$ 에서 빨리 자라는 붉은곰팡이가 잘 검출되었다가 저장 기간이 경과할수록 붉은곰팡이 오염립이 감소하면서 생장 속도가 느린 Drechslera 속의 검출이 용이해진 것으로 보인 다. 이밖에도 Phomopsis 및 Bipolaris 속이 검출되었으나 검출빈도가 대부분 $1 \%$ 이하로 나타났다(data not shown). 저장 곰팡이는 주로 곡물의 배젖 부분에 오염되는 반면 포장 곰팡이는 주로 껍질부분에 오염된다고 알려져 있다 (6). 따라서 본 연구에서는 곰팡이 오염 조사 시 겉보리 껍질 부분에 오염된 포장 곰팡이의 증식이 유리했을 것으로 보인다. 또한 곰팡이 오염 조사에 PDA 배지를 사용했기 때문에 건조한 조건에서 잘 자라는 저장 곰팡이의 검출이 용이하지 못했을 수 있다.

\section{곰팡이독소 오염}

겉보리의 저장 초기 곰팡이독소 오염수준은 NIV가 DON 보다 높았으나 0.82-0.91 ppm 정도의 낮은 수준이었으며 $\mathrm{DON}$ 은 $0.1 \mathrm{ppm}$ 미만으로 국내산 보리에서 DON 보다 NIV 의 오염이 높다는 보고 $(27,28)$ 와 유사하였다(data not shown). 저장 3개월까지 시료의 NIV 오염수준에 유의한 변화는 없었으나, 저장 6 개월 후 시료 2의 오염수준이 크게 증가하였다(Table 1). 또한 저장소 간 NIV 오염에 유의차는 나타나지 않았다 $(\mathrm{p}<0.05)$. 곡물의 독성 곰팡이 오염이 반드 시 곰팡이독소의 오염을 수반하지는 않는다. Birzele 등(18) 에 의하면 수분함량이 $17 \%$ 와 $20 \%$ 인 밀을 $20^{\circ} \mathrm{C}$ 에 6 주 간 보관했을 때 Fusarium 속 오염립은 감소했으나 DON 농도 는 증가하여 오염립과 DON 농도가 양의 상관성이 없음을 시사했다. 또한 Homdork(23)는 밀을 다양한 습도에서 36주 간 저장했을 때 저장 후기로 갈수록 높은 습도에서 $\mathrm{DON}$ 의 농도가 유지되거나 감소한 반면 NIV 농도는 증가하였다고
Table 1. Level of nivalenol (ppm) in hulled barley during storage

\begin{tabular}{cccc}
\hline $\begin{array}{c}\text { Temperature/ } \\
\text { Relative humidity (\%) }\end{array}$ & Month & Sample 1 & Sample 2 \\
\hline \multirow{3}{*}{ No control 1 } & 0 & $0.91 \pm 0.10^{1)}$ & $0.82 \pm 0.03^{\mathrm{b}}$ \\
& 1 & $1.02 \pm 0.04$ & $0.66 \pm 0.03^{\mathrm{c}}$ \\
& 3 & $1.10 \pm 0.17$ & $0.67 \pm 0.03^{\mathrm{c}}$ \\
& 6 & $1.11 \pm 0.09$ & $1.79 \pm 0.05^{\mathrm{a}}$ \\
\hline No control 2 & 0 & $0.91 \pm 0.10^{\mathrm{b}}$ & $0.82 \pm 0.03$ \\
& 1 & $1.22 \pm 0.01^{\mathrm{a}}$ & $0.64 \pm 0.01^{\mathrm{b}}$ \\
& 3 & $1.19 \pm 0.06^{\mathrm{a}}$ & $0.86 \pm 0.02^{\mathrm{a}}$ \\
& 6 & $0.98 \pm 0.05^{\mathrm{b}}$ & $0.86 \pm 0.07^{\mathrm{a}}$ \\
\hline $12^{\circ} \mathrm{C}$ & 0 & $0.91 \pm 0.10$ & $0.82 \pm 0.03^{\mathrm{b}}$ \\
& 1 & $0.94 \pm 0.02$ & $0.67 \pm 0.01^{\mathrm{b}}$ \\
& 3 & $1.10 \pm 0.08$ & $0.64 \pm 0.05^{\mathrm{b}}$ \\
& 6 & $1.02 \pm 0.07$ & $1.43 \pm 0.48^{\mathrm{a}}$ \\
\hline $15^{\circ} \mathrm{C} / 65 \%$ & 0 & $0.91 \pm 0.10$ & $0.82 \pm 0.03^{\mathrm{b}}$ \\
& 1 & $1.27 \pm 0.11$ & $0.47 \pm 0.01^{\mathrm{b}}$ \\
& 3 & $1.29 \pm 0.39$ & $0.78 \pm 0.01^{\mathrm{b}}$ \\
& 6 & $1.16 \pm 0.08$ & $1.32 \pm 0.39^{\mathrm{a}}$ \\
\hline $10^{\circ} \mathrm{C}$ & 0 & $0.91 \pm 0.10^{\mathrm{b}}$ & $0.82 \pm 0.03^{\mathrm{b}}$ \\
& 1 & $1.25 \pm 0.05^{\mathrm{a}}$ & $0.62 \pm 0.03^{\mathrm{b}}$ \\
& 3 & $0.96 \pm 0.05^{\mathrm{b}}$ & $0.93 \pm 0.14^{\mathrm{b}}$ \\
& 6 & $1.36 \pm 0.12^{\mathrm{a}}$ & $1.65 \pm 0.26^{\mathrm{a}}$ \\
\hline
\end{tabular}

${ }^{1)}$ Small letters refer to group by Duncan's multiple range test $(\mathrm{p}<0.05)$.

보고하였다. Zhang(29)에 의하면 밀과 밀가루를 $18-27^{\circ} \mathrm{C}$ 의 상온과 $4^{\circ} \mathrm{C}$ 의 저온에 180 일 간 저장했을 때 $\mathrm{DON}$ 의 농도가 저장 후기로 갈수록 감소하였다. 이렇듯 곰팡이독소 오염 은 환경조건에 따라 생성되거나 감소하여 예측하기가 매우 어렵다. 특히 본 연구처럼 통제된 조건이 아닌, 자연적으로 수확한 보리를 실제 저장창고에서 저장하는 경우 저장온 도, 상대습도 및 곡물수분함량 외에도 보리의 품종과 품질, 오염된 곰팡이 종류와 양, 독소 생성능 및 해충의 유무 등 다양한 요인이 곰팡이 독소의 생성에 영향을 미칠 수 있다. 따라서 저장 중 곰팡이독소 생성을 최대한 억제할 수 있는 환경을 조성하는 것이 중요하다. 본 연구에서 겉보리 시료 2 의 경우 저장 6 개월 후 모든 저장소에서 NIV의 농도가 증가했으므로 저장 기간을 6개월 미만으로 줄이는 것이 곰팡이독소 저감화에 도움이 될 것으로 보인다. 한편 3개월 이후 어느 시점에서 NIV의 증가가 일어나는지 후속 연구를 통해 정확히 진단하는 것이 필요하다.

보리는 6 월에 수확하여 수분함량을 $14 \%$ 로 건조한 후 판매 전까지 저장하는데, 저장 초기 1-2개월은 온도와 습도 가 높은 여름이면서 장마철이 있어 이 기간 동안 창고의 습도 조절에 특히 유의해야 한다. 상온창고는 외부 기온의 영향을 많이 받아 온도와 곡물수분함량의 변화가 크고 포장 
곰팡이가 감소할 확률이 높지만 저장 곰팡이가 우점할 수 있다. 저온창고는 창고내부의 상대습도가 높아 곡물수분함 량이 높게 유지되고 저장 후기에도 Fusarium 속 곰팡이의 오염율이 높아 곰팡이독소의 오염 위험이 있다. 항온항습 실과 종자저장고는 온도와 습도가 낮고 곡물수분함량도 낮게 유지되어 곡물 저장에 이상적이었으나 저온창고와 마찬가지로 저장 후기 Fusarium 등 포장 곰팡이의 생존률이 높은 경항을 보였다.

본 연구는 저장한 시료의 양은 적지만 실제 저장 환경과 유사한 조건에서 실험하였다는데 의의가 있으며, 다양한 환경에서 저장 기간에 따른 균상의 변화와 NIV 오염량 조 사결과는 곰팡이독소 오염을 예방하기 위한 기초 자료로 활용될 수 있다. 그러나 Aspergillus 나 Penicillium 속 등 저장 곰팡이에 대한 조사가 충분치 못했으므로 저장 곰팡이 와 그에 따른 곰팡이독소 오염 구명을 위한 연구가 필요할 것으로 사료된다.

\section{요 약}

본 연구는 곰팡이독소에 안전한 보리 저장법을 수립하기 위해 다양한 저장환경 중 겉보리에 발생하는 곰팡이와 곰팡 이독소를 측정하였다. 두 지역에서 수집한 겉보리를 상온 창고 2곳, 저온창고, $15^{\circ} \mathrm{C} / 65 \%$ 항온항습실 및 종자저장고에 6개월간 저장하면서 장소별 온도, 상대습도 및 곡물수분함 량을 측정하였으며 $0,1,3$ 및 6 개월 후 겉보리에 오염된 곰팡이와 곰팡이독소를 조사하였다. 저장 중 보리에 오염 된 주요 곰팡이 속은 Fusarium, Epicoccum, Alternaria 및 Drechslera 이었다. 상온창고는 저장 후기로 갈수록 Fusarium 과 Alternaria 속 곰팡이가 큰 폭으로 감소한 반면 Drechslera는 증가하였다. 저온창고, 항온항습실 및 종자저 장고에서는 Fusarium 오염립의 감소폭이 적었고 저장 6개 월 후에도 $2.5 \log \mathrm{CFU} / \mathrm{g}$ 이상이 검출되었다. 니발레놀 오염 은 한 시료에서 저장 0-3개월 간 비슷한 수준을 유지하다가 6 개월 후 증가하였으며, 저장소 간 차이는 나타나지 않았다. 따라서 겉보리 저장 중 니발레놀 오염 예방을 위해 저장 기간을 6 개월 미만으로 줄이는 것이 효율적일 것으로 보 인다.

\section{감사의 글}

본 연구는 농촌진흥청 국립농업과학원 농업과학기술 연 구개발사업(과제번호: PJ010969)의 지원에 의해 이루어진 것임

\section{References}

1. Alshannaq A, Yu JH (2017) Occurrence, toxicity, and analysis of major mycotoxins in food. Int J Environ Res Public Health, 14, 632

2. Lee SH, Lee JK, Nam YJ, Lee SH, Ryu JG, Lee T (2010) Population structure of Fusarium graminearum from maize and rice in 2009 in Korea. Plant Pathol J, 26, 321-327

3. Marin S, Ramos AJ, Cano-Sancho G, Sanchis V (2013) Mycotoxins: Occurrence, toxicology, and exposure assessment. Food Chem Toxicol, 60, 218-237

4. Miller JD (1995) Fungi and mycotoxins in grain: Implications for stored product research. J Stored Prod Res, 31, 1-16

5. Taligoola HK, Ismail MA, Chebon SK (2011) Mycobiota and aflatoxins associated with imported rice grains stored in Uganda. Czech Mycol, 63, 93-107

6. Pinciroli M, Gribaldo A, Vidal A, Bezus R, Sisterna M (2013) Mycobiota evolution during storage of paddy, brown and milled rice in different genotypes. Summa Phytopathol, 39, 157-161

7. Choi J, Park J, Park G, Kim Y, Lee M, Oh Y, Choi I, Kim S, Kim T (2013) Barley. Rural Development Administration, Suwon, Korea, p 129

8. Kim S, Jo S, Kang C, Kim G, Kim H, Kim W, Ryu S, Hong S, Jo J, Park J (2014) Barley \& Wheat, GAP production guide. National Institute of Agricultural Sciences, Wanju, Korea, p 23-24

9. Lee T, Lee S, Kim LH, Ryu JG (2014) Occurrence of fungi and Fusarium mycotoxins in the rice samples from rice processing complexes. Res Plant Dis, 20, 289-294

10. Legzdina L, Buerstmayr H (2004) Comparison of infection with Fusarium head blight and accumulation of mycotoxins in grain of hulless and covered barley. J Cereal Sci, 40, 61-67

11. Clear R, Patrick SK, Nowicki T, Gaba D, Edney M, Babb JC (1997) The effect of hull removal and pearling on Fusarium species and trichothecenes in hulless barley. Can J Plant Sci, 77, 161-166

12. Ham H, Lee KA, Lee T, Han S, Hong SK, Lee S, Ryu JG (2017) Effects of storage temperature and grain moisture content on the contamination of Fusarium and Fusariotoxin in hulled barley grains. J Food Hyg Saf, 32, 321-328

13. Lee T, Kim S, Busman M, Proctor RH, Ham H, Lee S, Hong SK, Ryu JG (2015) Rapid detection method 
for fusaric acid-producing species of Fusarium by PCR. Res Plant Dis, 21, 326-329

14. White TJ, Bruns T, Lee S, Taylor J (1990) Amplification and direct sequencing of fungal ribosomal RNA genes for phylogenetics. In: PCR protocols: a guide to methods and applications, Innis MA, Gelfand DH, Sninsky JJ, White TJ, Academic Press Inc, NY, USA, p 315-322

15. O’Donnell K, Kistler HC, Cigelnik E, Ploetz RC (1998) Multiple evolutionary origins of the fungus causing Panama disease of banana: Concordant evidence from nuclear and mitochondrial gene genealogies. Proc Natl Acad Sci USA, 95, 2044-2049

16. van Wyk PS, Scholtz DJ, Los O (1986) A selective medium for the isolation of Fusarium spp. from soil debris. Phytophylactica, 18, 67-69

17. Beattie S, Schwarz PB, Horsley R, Barr J, Casper HH (1998) The effect of grain storage conditions on the viability of Fusarium and deoxynivalenol production in infested malting barley. J Food Prot, 61, 103-106

18. Birzele B, Prange A, Kramer J (2000) Deoxynivalenol and ochratoxin $\mathrm{A}$ in German wheat and changes of level in relation to storage parameters. Food Addit Contam, 17, 1027-1035

19. Choi S, Jun H, Bang J, Chung SH, Kim Y, Kim BS, Kim H, Beuchat LR, Ryu JH (2015) Behaviour of Aspergillus flavus and Fusarium graminearum on rice as affected by degree of milling, temperature, and relative humidity during storage. Food Microbiol, 46, 307-313

20. Ramirez ML, Chulze S, Magan N (2006) Temperature and water activity effects on growth and temporal deoxynivalenol production by two Argentinean strains of Fusarium graminearum on irradiated wheat grain. Int J Food Microbiol, 106, 291-296
21. Schrodter R (2004) Influence of harvest and storage conditions on trichothecenes levels in various cereals. Toxicol Lett, 153, 47-49

22. Magan N, Lacey J (1985) Interactions between field, and storage fungi on wheat grain. Trans Br Mycol Soc, 85, 29-37

23. Homdork S, Fehrmann H, Beck R (2000) Influence of different storage conditions on the mycotoxin production and quality of Fusarium-infected wheat grain. J Phytopathol, 148, 7-15

24. White NDG, Hulasare RB, Jayas DS (1999) Effects of storage conditions on quality loss of hull-less and hulled oats and barley. Can J Plant Sci, 79, 475-482

25. Singh DB (1980) Effect of culture media, $\mathrm{pH}$ and temperature on growth behaviour of Alternaria brassicae and Drechslera graminea. Proc Indian natn Sci Acad, B46, 393-396

26. Wiewiora B, Pronczuk M (2002) Rhizoctonia solani and other fungi detected in perennial ryegrass seeds after harvest and storage. Phytopathol Pol, 26, 19-27

27. Kim JC, Kang HJ, Lee DH, Lee YW, Yoshizawa T (1993) Natural occurrence of Fusarium mycotoxins (trichothecenes and zearalenone) in barley and corn in Korea. Appl Environ Microbiol, 59, 3798-3802

28. Ryu JG, Lee SH, Lee SH, Son SW, Nam YJ, Kim MJ, Lee T, Yun JC (2011) Natural occurrence of Fusarium head blight and its mycotoxins in 2010- harvested barley and wheat grains in Korea. Res Plant Dis, 17, 272-279

29. Zhang H, Sun J, Zhang Y, Lu M, Sun L, Li W, Hu X, Wang B (2016) Retention of deoxynivalenol and its derivatives during storage of wheat grain and flour. Food Control, 65, 177-181 